\title{
Study on Causal Association between FDI and Its Determinants in Taiwan
}

\author{
Shailender Singh ${ }^{1 *}$, Pooja Jain ${ }^{2}$ \\ ${ }^{1}$ Department of Commerce, SRM University, Amaravati, India \\ ${ }^{2}$ Shri Guru Ram Rai University, Dehradun, India \\ Email: ^reshu111us@yahoo.com,dr.pujajain@gmail.com
}

How to cite this paper: Singh, S. and Jain, P. (2018) Study on Causal Association between FDI and Its Determinants in Taiwan. Theoretical Economics Letters, 8, 3470-3480.

https://doi.org/10.4236/tel.2018.815213

Received: August 6, 2018

Accepted: December 2, 2018

Published: December 5, 2018

Copyright $\odot 2018$ by authors and Scientific Research Publishing Inc. This work is licensed under the Creative Commons Attribution International License (CC BY 4.0).

http://creativecommons.org/licenses/by/4.0/

\begin{abstract}
A vital role is played by FDI (Foreign Direct Investment) in enhancing the growth and economic status of the country. Most of the countries in the developing phase depend on FDI to foster their economy as they were facing the scarcity of hard cash for their development process. High growth performance experienced by Taiwan economy largely relies on the FDI; to attract the foreign capital inflows the Taiwan government work on many policies. But the most important factors which influence and attract the foreign capital inflows are in academic debate. On the basis of macroeconomic theory knowledge, this research paper will shed light on the econometric analysis on the data of Taiwan's total foreign direct investment and factors influencing it, which contains exchange rate, inflation rate, Taiwan stock exchange index, import, and business income tax during the years of 1998 to 2013.
\end{abstract}

\section{Keywords}

Exchange Rate, FDI, ARDL, Granger Causality, Net Export, VECM

\section{Introduction}

Despite the good statistics and recognitions, Taiwan is facing a number of challenges. Based on the World Economic Forum's executive opinion survey, political instability and the insufficient capacity to innovate top the list of most problematic factors for doing business in Taiwan as perceived by Taiwanese executives. According to the World Economic Forum (WEF) Taiwan ranked as the world's $15^{\text {th }}$ most competitive economy in 2016 [1]. This was better than the majority of Asian countries/areas; only Singapore $\left(2^{\text {nd }}\right)$, Japan $\left(6^{\text {th }}\right)$, and Hong Kong SAR $\left(7^{\text {th }}\right)$ ranked higher. Taiwan was the world's $26^{\text {th }}$ largest economy in 2015 with a gross domestic product (GDP) of 523,009 million USD (22,263 USD 
per capita), and it was growing at a rate of 3.4\% per annum during 2010-2015. The GDP of Taiwan was composed of exports (69.9\%), imports (59.6\%), domestic household consumption (53.3\%), gross capital formation $(21.8 \%)$, and government consumption (14.5\%). In the 1980s, the increasing cost of labor and the approval of Taiwanese dollar were repeatedly cited as a reason for Taiwan's failure to magnetize foreign business, on the other hand, their regional peers did not make any change in all these things and enjoying business from foreign. However, today the bureaucratic obstacles, uncompetitive tax system, poor protection schemes for investors, weak contract enforcements, and comparatively poor regional economic integration are the main factors which are responsible for the failure of Taiwan's policies to catch the attention of foreign direct investment [2].

The "deindustrialization" of Taiwan is demonstrated by the rising inconsistency among inflows and outflows of FDI. Only the semiconductor industries are the exceptions, as they continue their investments in the Research \& Development and in the capital equipment for their expansion in productions, many of the manufacturing industries of Taiwan have lost their investment at home.

Since 1997, Taiwan's inflowing investments are constantly lesser than the out flowing investments. During 2000 to 2012, Taiwan's outflow investments are extended to $\$ 165$ billion, which is four times higher than the inflow investments ( $\$ 40$ billion). In 2012; Taiwan's stock of incoming Foreign Direct Investment was valued nearly $\$ 60$ billion - not very much higher than the $\$ 50$ billion as in 2006. In 2012, FDI flows within Taiwan were $\$ 4.7$ billion, whereas they were more than $\$ 16$ billion in Korea, its adjoining rival [2].

This paper is committed to dissecting the degree to which those determinants influence the FDI inflows in creating nations. Alluding to prior studies led either in the rising or propelled economies on FDI inflows, researchers hold diverse perspectives on the presence or heading of causality between FDI and its determinants. Prior investigations looking into this area reported blended and uncertain results. This might be incomplete because of various reasons. Examining the FDI with diverse techniques, a set of information, and a sample of the study might prompt the conflicting findings. This study is, in this manner went for experimentally rethinking the short and long-run connections among FDI and its determinants (CPI, XR, TWSE, IMP, and BIT) in the Taiwan economy during the period of 1998-2016 by embracing the most recent procedure, autoregressive distributed lag (ARDL) test for validation of co-integration. Furthermore, the study likewise endeavors examination of FDI of Taiwan utilizing error correction mechanism taking into account VAR framework.

The aim of this paper is to test an ARDL model for the FDI inflows in Taiwan ensuing from the approach adopted by Pesaran [3]. The model to be validated is an autoregressive distributed lag (ADL) one where the dependent variable is regressed on its lags. The paper is organized as follows: Section 1 presents an Introduction of the Study; Section 2 discusses the Research Framework, which is comprised of Data Source, Time Period and Model Specification. Section 3 is 
presenting the results and findings, including Unit Root Tests, Johansen Co-integration Test, Estimation of VEC Model and Graphical Presentation of Impulse Response Functions. Finally, Section 4 concludes and highlights policy implications for future research.

\section{Research Framework}

\subsection{Data Source}

This research work is completed in context to the Taiwan economy during the time of 1998-2016 on the monthly premise contains 218 perceptions, which ought to be satisfactory to validate the association of cointegration among the variables used in the study. The information arrangement required includes FDI (Foreign Direct Investment), CPI (Consumer Price Index), XR (Exchange Rate), TWSE (Taiwan Stock Exchange), IMP (Import) and BIT (Business Income Tax). All the information utilized to conduct the research was retrieved from Taiwan Economic Journal (TEJ) and reports published by the Asian Development Bank. The variables incorporated in this exploration are FDI as a dependent variable and CPI, XR, TWSE, IMP and BIT as independent variables. All the variables used in the study are converted into the logged version for better results of time series analysis.

\subsection{Model Specification}

In the present research work, the short and long-run progressive associations among FDI and its determinants are assessed with the help of utilizing ARDL Test that was originally exhibited by Pesaran et al. in 1996 [3]. ARDL approach gives vigorous results to a slighter small sample size for co-integration investigation. Subsequent to the smaller size of sample for present research, it welcomes the appropriateness of ARDL model for the present study. The ARDL model utilized within this research is composed of as follow:

$$
\begin{aligned}
\ln F D I_{t}= & \beta_{o}+\beta_{1} \ln C P I_{t}+\beta_{2} \ln X R_{t}+\beta_{3} \ln T W S E_{t} \\
& +\beta_{4} \ln I M P_{t}+\beta_{5} \ln B I T_{t}+e_{t}
\end{aligned}
$$

where $\ln$ is Natural Logarithm, $F D I_{t}$ is Foreign Direct Investment at time $t, C P I_{t}$ as an assessment of inflation, $X R_{t}$ is the exchange rate, $T W S E_{t}$ is an index of Taiwan stock exchange, $I M P_{t}$ represents import, $B I T_{t}$ shows Business income tax and $e_{t}$ is an error term.

The variables in the Equation (1) could be reframed as follows by considering ARDL framework:

$$
\begin{aligned}
\Delta \ln F D I= & \delta_{O}+\sum_{i=1}^{p} \varepsilon_{i} \Delta \ln F D I_{t-1}+\sum_{i=1}^{p} \phi_{i} \Delta \ln C P I_{t-1}+\sum_{i=1}^{p} \varphi_{i} \Delta \ln X R_{t-1} \\
& +\sum_{i=1}^{p} \gamma_{i} \Delta \ln T W S E_{t-1}++\sum_{i=1}^{p} \vartheta_{i} \Delta \ln I M P_{t-1}+\sum_{i=1}^{p} \vartheta_{i} \Delta \ln B I T_{t-1} \\
& +\lambda_{1} \ln F D I_{t-1}+\lambda_{2} \ln C P I_{t-1}+\lambda_{3} \ln X R_{t-1}+\lambda_{4} \ln T W S E_{t-1} \\
& +\lambda_{5} \ln I M P_{t-1}+\lambda_{6} \ln B I T_{t-1}+\mu_{t}
\end{aligned}
$$




\section{Results and Findings}

\subsection{Descriptive Analysis}

Descriptively, the means and standard deviation scores were computed in order to determine the variability of the spread of data as shown in Table 1.

\subsection{Unit Root Tests}

To check stationary properties for the time series that was used in the VECM model, two of the well-known stationary tests Augmented Dickey-Fuller (ADF) and Phillips-Perron (PP) were used by assuming that null hypothesis supports the non-stationary properties of time series. So the denial for the unit root hypothesis favors the stationary property. Findings are depicted in Table 2 and Table 3 in the form of $t$-test values along with their $p$-values for all five variables of the model. Both tests criteria indicate that all the dependent and independent variables used in the research work have the tendency of non-stationery properties in time series when ADF and PP test were executed at level.

Table 1. Descriptive statistics collected for all the variables.

\begin{tabular}{|c|c|c|c|c|c|c|}
\hline & LFDI & LCPI & LXR & LTWSE & LIMP & LBIT \\
\hline Mean & 9.241335 & -0.114094 & 3.468366 & 5.628042 & 8.004679 & 15.76479 \\
\hline Median & 9.306421 & 0.122178 & 3.474696 & 5.632483 & 8.018790 & 15.46867 \\
\hline Maximum & 12.23858 & 1.759581 & 3.558543 & 6.086479 & 8.324336 & 19.09150 \\
\hline Minimum & 4.990433 & -4.605170 & 3.359055 & 5.072859 & 7.592366 & 8.696343 \\
\hline Std. Dev. & 1.245763 & 1.085847 & 0.052462 & 0.188016 & 0.128342 & 1.779084 \\
\hline Skewness & -0.325949 & -1.280895 & -0.213518 & -0.498061 & -0.448131 & -0.215128 \\
\hline Kurtosis & 3.817165 & 5.431497 & 2.066314 & 3.489724 & 3.123319 & 3.153775 \\
\hline Jarque-Bera & 9.925627 & 113.3141 & 9.575011 & 11.19149 & 7.434654 & 1.896297 \\
\hline Probability & 0.006993 & 0.000000 & 0.008333 & 0.003714 & 0.024299 & 0.387458 \\
\hline Sum & 2014.611 & -24.87255 & 756.1039 & 1226.913 & 1745.020 & 3436.724 \\
\hline
\end{tabular}

Source: Data analysis.

Table 2. Outcome of the ADF test at level \& $1^{\text {st }}$ difference.

\begin{tabular}{|c|c|c|c|c|c|c|c|c|c|c|c|c|}
\hline \multirow{3}{*}{ Variables } & \multicolumn{6}{|c|}{ Level } & \multicolumn{6}{|c|}{$1^{\text {st }}$ Difference } \\
\hline & \multicolumn{3}{|c|}{ Intercept but no trend } & \multicolumn{3}{|c|}{ Intercept and trend } & \multicolumn{3}{|c|}{ Intercept but no trend } & \multicolumn{3}{|c|}{ Intercept and trend } \\
\hline & $\begin{array}{c}\text { Test } \\
\text { Statistics }\end{array}$ & $\begin{array}{c}\text { Critical } \\
\text { Value }(5 \%)\end{array}$ & Prob. & $\begin{array}{c}\text { Test } \\
\text { Statistics }\end{array}$ & $\begin{array}{c}\text { Critical } \\
\text { Value (5\%) }\end{array}$ & Prob. & $\begin{array}{c}\text { Test } \\
\text { Statistics }\end{array}$ & $\begin{array}{c}\text { Critical } \\
\text { Value }(5 \%)\end{array}$ & Prob. & $\begin{array}{c}\text { Test } \\
\text { Statistics }\end{array}$ & $\begin{array}{c}\text { Critical } \\
\text { Value }(5 \%)\end{array}$ & Prob. \\
\hline LFDI & -1.281 & -2.875 & 0.639 & -7.407 & -3.431 & 0.000 & -8.153 & -2.875 & 0.000 & -8.201 & -3.432 & 0.000 \\
\hline LCPI & -6.463 & -2.875 & 0.000 & -6.484 & -3.431 & 0.000 & -8.875 & -2.875 & 0.0000 & -8.853 & -3.431 & 0.0000 \\
\hline LXR & -2.291 & -2.875 & 0.176 & -2.695 & -3.431 & 0.239 & -12.850 & -2.875 & 0.0000 & -12.812 & -3.431 & 0.0010 \\
\hline LTWSE & -3.777 & -2.875 & 0.003 & -3.931 & -3.431 & 0.012 & -6.123 & -2.875 & 0.000 & -6.105 & -3.431 & 0.000 \\
\hline LIMP & -3.622 & -2.875 & 0.006 & -4.335 & $-3 . .432$ & 0.003 & -3.505 & $-2 . .875$ & 0.008 & -3.494 & -3.432 & 0.0423 \\
\hline LBIT & -2.185 & -2.875 & 0.213 & -2.194 & -3.432 & 0.490 & -24.617 & $-2 . .875$ & 0.000 & -24.591 & -3.432 & 0.000 \\
\hline
\end{tabular}

Source: Data analysis. 
Table 3. Outcome of PP test at level \& $1^{\text {st }}$ difference.

\begin{tabular}{|c|c|c|c|c|c|c|c|c|c|c|c|c|}
\hline \multirow{3}{*}{ Variables } & \multicolumn{6}{|c|}{ Level } & \multicolumn{6}{|c|}{$1^{\text {st }}$ Difference } \\
\hline & \multicolumn{3}{|c|}{ Intercept but no trend } & \multicolumn{3}{|c|}{ Intercept and trend } & \multicolumn{3}{|c|}{ Intercept but no trend } & \multicolumn{3}{|c|}{ Intercept and trend } \\
\hline & $\begin{array}{c}\text { Test } \\
\text { Statistics }\end{array}$ & $\begin{array}{c}\text { Critical } \\
\text { Value (5\%) }\end{array}$ & Prob. & $\begin{array}{c}\text { Test } \\
\text { Statistics }\end{array}$ & $\begin{array}{c}\text { Critical } \\
\text { Value (5\%) }\end{array}$ & Prob. & $\begin{array}{c}\text { Test } \\
\text { Statistics }\end{array}$ & $\begin{array}{c}\text { Critical } \\
\text { Value (5\%) }\end{array}$ & Prob. & $\begin{array}{c}\text { Test } \\
\text { Statistics }\end{array}$ & $\begin{array}{c}\text { Critical } \\
\text { Value (5\%) }\end{array}$ & Prob. \\
\hline LFDI & -12.189 & -2.875 & 0.000 & -13.005 & -3.431 & 0.000 & -90.360 & -2.875 & 0.000 & -99.074 & -3.431 & 0.000 \\
\hline LCPI & -8.588 & -2.875 & 0.000 & -8.620 & -3.431 & 0.000 & -33.360 & -2.875 & 0.000 & -33.246 & -3.431 & 0.000 \\
\hline LXR & -2.413 & -2.875 & 0.139 & -2.399 & -3.431 & 0.379 & -12.851 & -2.875 & 0.000 & -12.813 & -3.431 & 0.000 \\
\hline LTWSE & -3.267 & -2.875 & 0.017 & -3.355 & $-3 . .431$ & 0.060 & -14.663 & -2.875 & 0.000 & -14.656 & -3.431 & 0.000 \\
\hline LIMP & -4.814 & -2.875 & 0.000 & -5.086 & -3.431 & 0.000 & -22.713 & -2.875 & 0.000 & -22.647 & -3.431 & 0.000 \\
\hline LBIT & -11.224 & -2.875 & 0.000 & -11.199 & -3.431 & 0.000 & -28.014 & -2.875 & 0.000 & -27.943 & -3.431 & 0.000 \\
\hline
\end{tabular}

Source: Data analysis.

When ADF Test is perform with the Level of series, the calculated T-statistics (with no trend and with trend) for LFDI $(-1.281 \&-2.407)$, LXR $(-2.291 \&$ $-2.695) \&$ LBIT $(-2.185 \&-2.194)$ is larger than critical values of LFDI $(-2.875$ \& -3.431$)$, LXR $(-2.875 \&-3.431)$ \& LBIT $(-2.875 \&-3.432)$ respectively at the significance level of $5 \%$. While the rest of the three variables (LCPI, LTWSE \& LIMP) demonstrates achieving stationary in level itself being there T-Statistics lower than critical values. It shows that $\mathrm{H}_{0}$ of unit root is accepted for the variables LFDI, LXR \& LBIT which demonstrate the presence of unit root problem and rejection of variables LCPI, LTWSE \& LIMP, which shows their stationary properties. When ADF Test is executed at first difference of series, the calculated value of T-statistics at significance level of $5 \%$ considering trend and no trend for LFDI (-8.153 \& -8.201), LCPI (-8.875 \& -8.853), LXR (-12.850 \& -12.812), LTWSE (-6.123 and -6.105$)$, LIMP $(-3.505 \&-3.494) \&$ LBIT $(-24.617 \&$ $-24.591)$ is smaller than critical values of LFDI $(-2.875 \&-3.432)$, LCPI $(-2.875$ $\&-3.431)$, LXR $(-2.875 \&-3.431)$, LTWSE $(-2.875 \&-3.431)$, LIMP $(-2.875 \&$ $-3.432) \&$ LBIT $(-2.875 \&-3.432)$ respectively. This means that $\mathrm{H}_{0}$ for unit root is rejected for all six variables, which implies that the first difference series of LFDI, LCPI, LXR, LTWSE, LIMP and LBIT achieves stationarity.

Results showed by Phillips-Perron test at level of series reveals that computed T-statistics (with no trend and with trend) for LXR $(-2.413 \&-2.399)$ is larger than critical values of LXR $(-2.875 \&-3.431)$ at the $5 \%$ significance level. While result shows that the computed T-statistics for rest of the five variable (LFDI, LCPI, LTWSE, LIMP \& LBIT) is lesser than their critical values, thereby evidencing the existence of stationary at level. P-P unit root test at first difference of series also indicates that the computed T-statistics at significance level of 5\% considering trend and no trend for LFDI $(-90.360 \&-99.074)$, LCPI $(-33.360 \&$ -33.246), LXR (-12.851 \& -12.813), LTWSE (-14.663 and -14.656), LIMP $(-22.713 \&-22.647) \&$ LBIT $(-28.014 \&-27.943)$ is smaller than critical values of LFDI $(-2.875 \&-3.431)$, LCPI $(-2.875 \&-3.431)$, LXR $(-2.875 \&-3.431)$, 
LTWSE (-2.875 \& -3.431), LIMP (-2.875 \& -3.431) \& LBIT (-2.875 \& -3.431) respectively at the $5 \%$ level of significance. It shows that null hypothesis for unit root is rejected for all six variables, which signify the achievement of stationarity. Here we have the pre-condition for co-integration test i.e., the variables are integrated of the same order. The study, therefore, proceeds to the co-integration test to attain the numbers of co-integrating equation.

\subsection{Johansen Co-Integration Test}

As a result, Johansen co-integration test is used to find out whether there is any long duration co-integration relationship among LFDI and other five variables (LCPI, LXR, LTWSE, LIMP \& LBIT) in Taiwan or not. In order to check the co-integration among the variables, Trace Statistics and Max Eigen Statistics have been tested by assuming the linear deterministic trend with a lag of 1 to 4 for each time series. To determine the number of co-integration equation, this approach focuses on the rank of matrix $S$, the count for independent co-integrating vectors will represent the rank (the sum of its non-zero Eigen-values). The null hypothesis of having co-integration will be rejected if the calculated value exceeds the tabulated value.

Table 4 depicts the results of co-integration test for Johansen. It declares the long-lasting association with the selected variables. The outcome explains that the series is co-integrated, as trace and maximum eigenvalue tests both reject the $\mathrm{H}_{0}$ of no co-integration $(\mathrm{r}=0)$ @ 5\% significance level. Table 4 reveals the statistics of trace which signify that here are at least five (5) co-integrating equations connecting LFDI and other five variables (LCPI, LXR, LTWSE, LIMP \& LBIT) in Taiwan at 5 percent, which means that the variables move together for long lasting. As shown in above Table 3 the Max-Eigen statistics indicate that there are four (4) co-integrating equation among LFDI \& other five variables (LCPI, LXR, LTWSE, LIMP \& LBIT) in Taiwan.

It was concluded from the outcome that, the trace and maximum Eigenvalue both confirms a strong value 4 co-integration. Critical Value is lower than Trace

Table 4. Johansen-Juselius co-integration test.

\begin{tabular}{|c|c|c|c|c|}
\hline \multirow{2}{*}{ Hypothesized No. of CE (s) } & \multirow{2}{*}{ Trace Statistic } & \multirow{2}{*}{ Max-Eigen Statistic } & \multicolumn{2}{|c|}{ Critical Value (5\%) } \\
\hline & & & Trace & Max-Eigen \\
\hline$r=0$ & $210.0199^{*}$ & $90.65172^{*}$ & 95.75366 & 40.07757 \\
\hline$r \leq 1$ & $119.3682^{*}$ & $47.97187^{*}$ & 69.81889 & 33.87687 \\
\hline$r \leq 2$ & $71.39631^{*}$ & $37.50389^{*}$ & 47.85613 & 27.58434 \\
\hline$r \leq 3$ & $33.89242^{*}$ & 20.89355 & 29.79707 & 21.13162 \\
\hline $\mathrm{r} \leq 4$ & 12.99887 & 8.370233 & 15.49471 & 14.26460 \\
\hline$r \leq 5$ & $4.628640^{*}$ & $4.628640^{*}$ & 3.841466 & 3.841466 \\
\hline
\end{tabular}

Note: ${ }^{\star}$ At a Significance level of $5 \%$ hypothesis will be rejected. Source: Data analysis. 
Statistic@5 percent significance for five co-integrations, showing that, it has a long run association of co-integrating relation among different variables. Now when we discuss about the unrestricted co-integration, the outcome from it shows a long run link. The Max-Eigen Value is more than Critical Value supporting four co-integrations. As a result, it might conclude that a stationary \& long-run relationship is present within variables.

\subsection{Estimating a VEC Model}

The presence of co-integration among variables under study offered ascends to the estimation of VEC Model. The impact of the error correction term demonstrates regarding the weight of smaller endogenous conformity (to the long-term pattern) to take the framework back to longer harmony. Up to a specific degree, causality fundamentally involves altogether of developments in the time series. After identifying the existence of co-integrating vector, VECM could be composed as:

$$
\begin{aligned}
& \Delta \ln F D I_{t}=\alpha_{1}+\sum_{i=1}^{l} \Phi_{1} \Delta \ln C P I_{t-1}+\sum_{i=1}^{m} \Omega_{1} \Delta \ln X R_{t-1}+\sum_{i=1}^{n} \gamma_{1} \Delta \ln T W S E_{t-1} \\
& +\sum_{i=1}^{o} \omega_{1} \Delta \ln I M P_{t-1}+\sum_{i=1}^{p} \vartheta_{1} \Delta \ln B I T_{t-1}+\sum_{i=1}^{q} \xi_{1} \Delta \ln F D I_{t-1}+\Psi_{1} E C T_{t-1}+\varepsilon_{1 t} \\
& \Delta \ln C P I_{t}=\alpha_{2}+\sum_{i=1}^{l} \Phi_{2} \Delta \ln F D I_{t-1}+\sum_{i=1}^{m} \Omega_{2} \Delta \ln X R_{t-1}+\sum_{i=1}^{n} \gamma_{2} \Delta \ln T W S E_{t-1} \\
& +\sum_{i=1}^{o} \omega_{2} \Delta \ln I M P_{t-1}+\sum_{i=1}^{p} \vartheta_{2} \Delta \ln B I T_{t-1}+\sum_{i=1}^{q} \xi_{2} \Delta \ln C P I_{t-1}+\Psi_{2} E C T_{t-1}+\varepsilon_{2 t} \\
& \Delta \ln X R_{t}=\alpha_{3}+\sum_{i=1}^{l} \Phi_{3} \Delta \ln F D I_{t-1}+\sum_{i=1}^{m} \Omega_{3} \Delta \ln C P I_{t-1}+\sum_{i=1}^{n} \gamma_{3} \Delta \ln T W S E_{t-1} \\
& +\sum_{i=1}^{o} \omega_{3} \Delta \ln I M P_{t-1}+\sum_{i=1}^{p} \vartheta_{3} \Delta \ln B I T_{t-1}+\sum_{i=1}^{q} \xi_{3} \Delta \ln X R_{t-1}+\Psi_{3} E C T_{t-1}+\varepsilon_{3 t} \\
& \Delta \ln T W S E_{t}=\alpha_{4}+\sum_{i=1}^{l} \Phi_{4} \Delta \ln F D I_{t-1}+\sum_{i=1}^{m} \Omega_{4} \Delta \ln C P I_{t-1}+\sum_{i=1}^{n} \gamma_{4} \Delta \ln X R_{t-1} \\
& +\sum_{i=1}^{o} \omega_{4} \Delta \ln I M P_{t-1}+\sum_{i=1}^{p} \vartheta_{4} \Delta \ln B I T_{t-1}+\sum_{i=1}^{q} \xi_{4} \Delta \ln T W S E_{t-1}+\Psi_{4} E C T_{t-1}+\varepsilon_{4 t} \\
& \Delta \ln I M P_{t}=\alpha_{5}+\sum_{i=1}^{l} \Phi_{5} \Delta \ln F D I_{t-1}+\sum_{i=1}^{m} \Omega_{5} \Delta \ln C P I_{t-1}+\sum_{i=1}^{n} \gamma_{5} \Delta \ln X R_{t-1} \\
& +\sum_{i=1}^{o} \omega_{5} \Delta \ln T W S E_{t-1}+\sum_{i=1}^{p} \vartheta_{5} \Delta \ln B I T_{t-1}+\sum_{i=1}^{q} \xi_{5} \Delta \ln I M P_{t-1}+\Psi_{5} E C T_{t-1}+\varepsilon_{5 t} \\
& \Delta \ln B I T_{t}=\alpha_{6}+\sum_{i=1}^{l} \Phi_{6} \Delta \ln F D I_{t-1}+\sum_{i=1}^{m} \Omega_{6} \Delta \ln C P I_{t-1}+\sum_{i=1}^{n} \gamma_{6} \Delta \ln X R_{t-1} \\
& +\sum_{i=1}^{o} \omega_{6} \Delta \ln T W S E_{t-1}+\sum_{i=1}^{p} \vartheta_{6} \Delta \ln I M P_{t-1}+\sum_{i=1}^{q} \xi_{6} \Delta \ln B I T_{t-1}+\Psi_{6} E C T_{t-1}+\varepsilon_{6 t}
\end{aligned}
$$

where $\varepsilon_{i t}$ is serially uncorrelated random error term. In this Vector Error correction model the $E C T_{t-1}$ coefficients $\Psi_{1}$ to $\Psi_{6}$ capture the adjustments of $\Delta \operatorname{lnFDI}, \Delta \operatorname{lnCPI}, \Delta \ln \mathrm{XR}, \Delta \ln \mathrm{TWSE}, \Delta \ln I \mathrm{MP}$, and $\Delta \ln \mathrm{BIT}$. The outcomes of 
vector correction model (VECM) estimation results obtained from Equations (3a) to (3f) are depicted in Table 5. Analyzing the data from Granger Causality Test based on VECM, moving across through Equation No. (3a) horizontally the value of $E C T_{t-1}$ is showing statistically significant and negative at the level of significance of $5 \%$. With this, the existence of long-run Granger causality moving from LCPI, LXR, LTWSE, LIMP \& LBIT to LFDI is confirmed due to the negative sign of error correction term. The resulting analysis also reveals the short-run causality movements that show the Granger causality proceeding from LBIT to LFDI and LCPI to LFDI.

In aforesaid Table 5 Equation No. 3(b) indicates insignificant short-run and long-run equilibrium. A horizontal row of Equation No. (3c) indicates that LXR retorts to long-run equilibrium because the negative value of $E C T_{t-1}$ at a significance level of $5 \%$ substantiate long-run causality moving from LFDI, LCPI, LTWSE, LIMP, LBIT to LXR. In the same Equation No. (3c) Granger Causality movement may be a sense from the short-time perspective from LFDI to LXR. Equation No. (3d) reveals insignificant long-run causality however short-run movement could be analysed from LFDI to LTWSE. Equation No. (3e) affirms the ubiquity of long-run granger causality due to the presence of significant and negative value of $\mathrm{ECT}_{\mathrm{t}-1}$ but the movement is at a low speed from LFDI, LCPI, LXR, LTWSE, LBIT to LIMP. Furthermore, Equation (3f) also, indicates the movement of Granger Causality from LCPI to LBIT and LFDI to LBIT. The outcome of the study also affirms the bi-directional causality between LBIT and LFDI.

Table 5. Granger causality results based on VECM.

\begin{tabular}{|c|c|c|c|c|c|c|c|}
\hline \multirow{3}{*}{$\begin{array}{l}\text { Dependent } \\
\text { Variable }\end{array}$} & \multicolumn{6}{|c|}{ Independent Variables } & \multirow{3}{*}{$\begin{array}{c}\mathrm{ECT}_{\mathrm{t}-1} \\
\text { Coefficient } \\
\text { (T-Ratio) }\end{array}$} \\
\hline & \multicolumn{6}{|c|}{$\chi^{2}$ Statistics (Source of Causation) } & \\
\hline & $\Delta$ LFDI & $\Delta \mathrm{LCPI}$ & $\Delta \mathrm{LXR}$ & $\Delta$ LTWSE & $\Delta$ LIMP & $\Delta \mathrm{LBIT}$ & \\
\hline $\begin{array}{c}\text { Equation (3a) } \\
\Delta \text { LFDI }\end{array}$ & - & $\begin{array}{l}7.115^{\star *} \\
{[0.028]}\end{array}$ & $\begin{array}{c}0.364 \\
{[0.834]}\end{array}$ & $\begin{array}{c}2.564 \\
{[0.277]}\end{array}$ & $\begin{array}{c}2.299 \\
{[0.317]}\end{array}$ & $\begin{array}{c}15.162^{\star * *} \\
{[0.001]}\end{array}$ & $\begin{array}{l}-0.0168^{\star *} \\
(-2.0159)\end{array}$ \\
\hline $\begin{array}{c}\text { Equation (3b) } \\
\Delta \mathrm{LCPI}\end{array}$ & $\begin{array}{c}0.911 \\
{[0.634]}\end{array}$ & - & $\begin{array}{c}3.295 \\
{[0.193]}\end{array}$ & $\begin{array}{l}0.0 .546 \\
{[0.761]}\end{array}$ & $\begin{array}{c}3.059 \\
{[0.217]}\end{array}$ & $\begin{array}{c}3.023 \\
{[0.220]}\end{array}$ & $\begin{array}{c}0.0009 \\
(0.1350)\end{array}$ \\
\hline $\begin{array}{c}\text { Equation (3c) } \\
\Delta \mathrm{LXR}\end{array}$ & $\begin{array}{l}5.172^{\star} \\
{[0.075]}\end{array}$ & $\begin{array}{c}0.540 \\
{[0.763]}\end{array}$ & - & $\begin{array}{c}3.154 \\
{[0.207]}\end{array}$ & $\begin{array}{c}3.662 \\
{[0.160]}\end{array}$ & $\begin{array}{c}2.833 \\
{[0.242]}\end{array}$ & $\begin{array}{l}-0.0001^{* *} \\
(-1.7421)\end{array}$ \\
\hline $\begin{array}{c}\text { Equation (3d) } \\
\Delta \text { LTWSE }\end{array}$ & $\begin{array}{l}4.964^{*} \\
{[0.084]}\end{array}$ & $\begin{array}{c}0.560 \\
{[0.756]}\end{array}$ & $\begin{array}{c}3.789 \\
{[0.150]}\end{array}$ & - & $\begin{array}{c}0.889 \\
{[0.641]}\end{array}$ & $\begin{array}{c}0.780 \\
{[0.677]}\end{array}$ & $\begin{array}{l}0.0003^{*} \\
(0.6593)\end{array}$ \\
\hline $\begin{array}{c}\text { Equation (3e) } \\
\Delta \text { LIMP }\end{array}$ & $\begin{array}{c}0.743 \\
{[0.690]}\end{array}$ & $\begin{array}{c}0.059 \\
{[0.971]}\end{array}$ & $\begin{array}{c}1.837 \\
{[0.400]}\end{array}$ & $\begin{array}{c}1.653 \\
{[0.437]}\end{array}$ & - & $\begin{array}{c}71.553^{\star * *} \\
{[0.002]}\end{array}$ & $\begin{array}{l}-0.0023^{\star *} \\
(-4.6251)\end{array}$ \\
\hline $\begin{array}{c}\text { Equation (3f) } \\
\Delta \text { LBIT }\end{array}$ & $\begin{array}{l}0.471^{\star *} \\
{[0.029]}\end{array}$ & $\begin{array}{l}6.579^{* *} \\
{[0.037]}\end{array}$ & $\begin{array}{c}2.984 \\
{[0.225]}\end{array}$ & $\begin{array}{c}3.864 \\
{[0.145]}\end{array}$ & $\begin{array}{c}0.850 \\
{[0.654]}\end{array}$ & - & $\begin{array}{c}0.0947 \\
(7.6090)\end{array}$ \\
\hline
\end{tabular}

Source: Data analysis. Note: ${ }^{*},{ }^{*}$ and ${ }^{* * *}$ represents the significance level of $10 \%, 5 \%$ and $1 \%$ respectively. [...] Represent as p-value. 


\subsection{Impulse Response Functions}

To further explore the interaction between foreign direct investment and its determinants, the study proceeds to test the impulse response functions (IRFs) [4]. Figure 1 exhibits the generalized asymptotic impulse response function which includes 6 small figures. Each small figure illustrates the dynamic response of each target variable (LFDI, LCPI, LXR, LTWSE, LIMP \& LBIT) to a one-standarddeviation shock on itself and other variables. In each small figure, the horizontal axis presents the ten years following the shock. The vertical axis measures the yearly impact of the shock on each endogenous variable.

Impulse responsive function uses Vector Autoregressive to measure the responsiveness of a series when the shock is present in one of the variables and
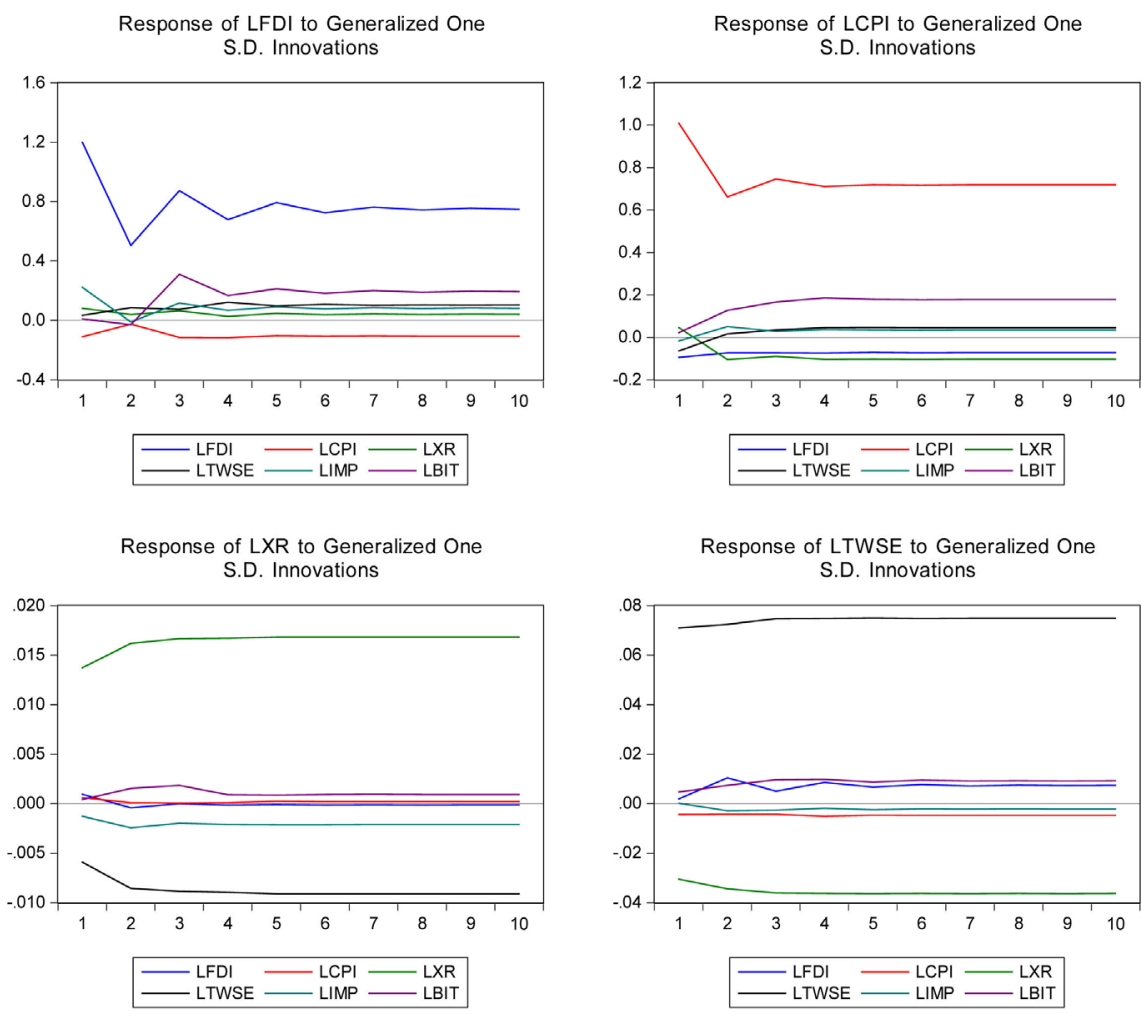

Response of LTWSE to Generalized One S.D. Innovations

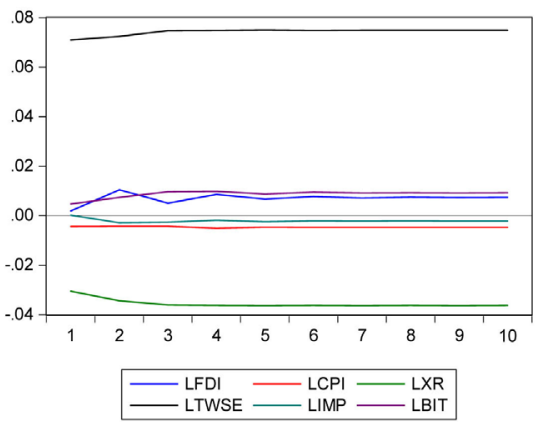

Response of LIMP to Generalized One S.D. Innovation

Response of LBIT to Generalized One S.D. Innovations
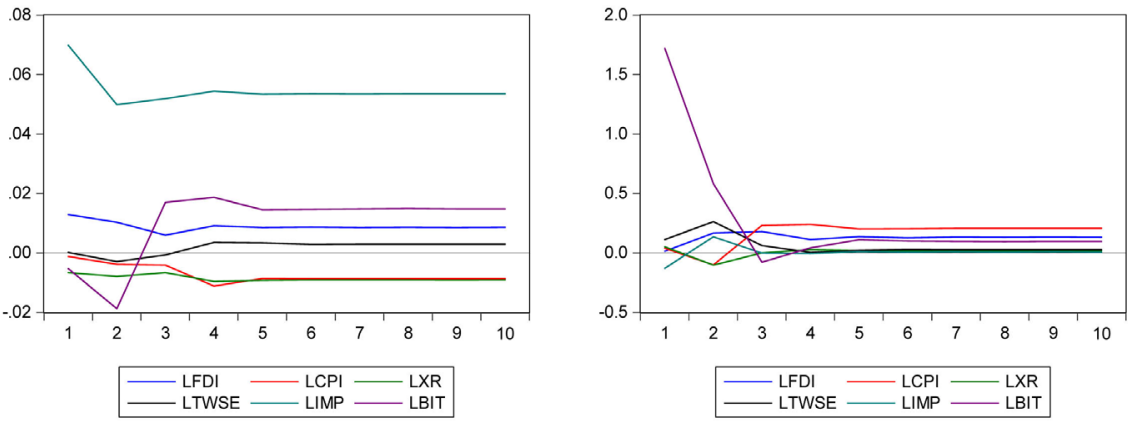

Figure 1. Generalized impulse response functions (GIFRS) lying underneath. Source: Eviews Result. 
exceeds the time period. Impulse Responsive functions give an indication of the system's dynamic behavior. Generalized impulse response functions (GIFRS) lying underneath in Figure 1, shows the response and impact of each and every macro-economic variable of VAR under study. In the VECM System, the GIRFs provides the support of causality status between foreign direct investment and its' determinants.

\section{Conclusions}

The study began by empirically examining the causal association among the selected macroeconomic variables (LCPI, LXR, LTWSE, LIMP, and LBIT) with the foreign direct investment (LFDI) in Taiwan during the period of 1998-2016. To conduct the research work, this study has used a multivariate VAR framework. In this, the time series data is analyzed first with stationary property examination. The probable consequences definite that LFDI, LCPI, LXR, LTWSE, LIMP, and LBIT are not stable under the confidence level of $5 \%$ but their first order difference terms are all stationary. Hence, they are integrated of order one. Results of study depict a long-run dynamic association of foreign direct investment with its macroeconomic variables. It is proved with the help of Johansen's multivariate co-integration analysis that $\mathrm{H}_{0}$ for no co-integration $(\mathrm{r}=0)$ is discarded (reject), this indicates that LFDI \& their determinants are co-integrated \& therefore it will reveal a trustworthy long-run relationship. In addition, the study agreed with the Granger-causality by the mean of VAR. The result demonstrates the existence of uni-directional causality linking the LBIT \& LFDI (LBIT $\rightarrow$ LFDI).

The findings of this research work may have significant implications for the national policy makers for helping in their decision-making process and can also fill the literature gap that will provide the further research opportunities to the researchers. Taiwan have regarded FDI increasingly as contributing to their development strategies for the technology and capital it applies, and therefore have made to compete for FDI. Policies about investment have become liberal at the national and regional level, but scientists still do not find the comprehensive framework for FDI at a multinational level. In the recent years, there are significant shifts towards liberalisation of the FDI regime, and FDI is considered more favorably now than a couple of decades ago. And now the government find out about the policies that can influence the impact of FDI on development. The kind of sequencing of general and special policies in areas covering investment, trade, innovation and human resources are all important.

\section{Conflicts of Interest}

The authors declare no conflicts of interest regarding the publication of this paper.

\section{References}

[1] World Economic Forum (2016) Global Competitiveness Report 2015-2016. 
[2] Wilson, W.T. (2014) Markets Solutions Should Be Central to U.S.'s Taiwan Policy. Backgrounder, 2930, 1-12.

[3] Pesaran, M.H., Shin, Y. and Smith, R.J. (1996) Testing for the Existence of a Long-Run Relationship. DAE Working Paper No. 9622. University of Cambridge, Cambridge.

[4] Pesaran, H.H. and Shin, Y. (1998) Generalized Impulse Response Analysis in Linear Multivariate Models. Economics Letters, 58, 17-29.

https://doi.org/10.1016/S0165-1765(97)00214-0 